\title{
The Public Effect of Private Sustainability Reporting: Evidence from Incident-Based Engagement Strategy
}

\author{
Natalia Semenova ${ }^{1}$ (D) \\ Received: 4 February 2021 / Accepted: 22 November 2021 / Published online: 2 December 2021 \\ (c) The Author(s) 2021
}

\begin{abstract}
This study examines whether private information exchange between institutional investors and public companies in engagement dialogs on sustainability issues improves the publicly disclosed measurements of the target company's financial and non-financial performance and transparency. It uses a unique dataset containing 326 private reports related to environmental, social, and anti-corruption recommendations to address material incidents among publicly traded MSCI World Index portfolio companies of Nordic institutional investors. The results indicate that target companies appear to have similar values with matched companies on sustainability performance and transparency ratings in the 3 years following the initiation of private reporting. Unexpected sustainability incidents are subsequently reflected in the next year's fall in the market value of target companies relative to MSCI World Index. This paper provides empirical evidence for the legitimacy-based provision of private sustainability information used in a larger disclosure system of public companies.
\end{abstract}

Keywords Risk management · Private engagement $\cdot$ Institutional investors $\cdot$ Sustainability risks $\cdot$ Sustainability reporting · Financial performance

\section{Introduction}

Private reporting and engagement dialogs with public companies on sustainability issues are becoming increasingly common strategies of active ownership. ${ }^{1}$ Active investors can engage in private dialog with the portfolio company management to contribute to a sustainable society, achieve incremental advances in the environmental and social conduct of investee companies, increase stock returns, and reduce potential material financial risks of portfolios in the long run (Barko et al., 2018; Bauer et al., 2015; Dimson et al., 2015; Eurosif, 2013, 2018). Research has provided extensive evidence, based on legitimacy theory, that broader stakeholder pressure from the news media, lobby groups, government, and customers can affect the level of company sustainability disclosure and performance (Blanc et al., 2017; Brown \& Deegan, 1998; Deegan, 2014; Deegan et al., 2002).

Natalia Semenova

natalia.semenova@lnu.se

1 School of Business and Economics, Linnaeus University, Universitetsplatsen 1, 35195 Växjö, Sweden
In particular, changes in the companies' sustainability practices can occur when an unexpected risk incident (i.e., "bad news") related to those companies is revealed through a public disclosure within the news media. Sustainability incidents have significant material implications for the involved companies in the form of compliance costs, lower stock prices, threatened reputation, and higher risks (Brammer \& Pavelin, 2006; Capelle-Blancard \& Petit, 2017; Kruger, 2015; Sharfman \& Fernando, 2008). Researchers claim that sustainability incidents can also trigger direct engagement between institutional investors and public companies, which is defined as private pressure (Dimson et al., 2015; PRI, 2018; Reid \& Toffel, 2009). Incident-based private engagement dialog is a widely used tactic of investor activism (Rehbein et al., 2013); however, this engagement option has received scant academic attention in broad-scale empirical research due to the lack of data and public transparency. Most broad-scale empirical research on private sustainability-related pressure of institutional investors has focused on negotiations aimed at the withdrawal of shareholder resolutions in the Anglo-Saxon governance perspective of the US.

\footnotetext{
${ }^{1}$ We use the term "private sustainability reporting" to refer to private, behind-the-scene information exchange between institutional investors and public companies in engagement dialogs on sustainability issues.
} 
Private pressure from active Nordic institutional investors in the form of incident-based dialogs with global, publicly traded companies prior to or independent of shareholder resolution forms the focus of investigation in this paper.

This paper examines whether the initiation of incidentbased private reporting on environmental, social, and corruption sustainability risks by Nordic institutional investors induces public knowledge about the public companies that is reflected in the non-financial performance and disclosure sustainability ratings of environmental, social, and governance (ESG) data providers and financial performance measures. That is, this paper aims to address the research question of whether private reporting in engagement dialogs with public companies on sustainability risks affects the publicly disclosed measurements of target company financial and non-financial performance and transparency. By its nature, such private sustainability reporting is hidden from public view; however, its effects can be visible in the sustainabilityrelated operations of the target companies because institutional investors attempt to convey new information about suggested improvements to managers (Barko et al., 2018; Cundill et al., 2018). The demand for changes in the target companies' sustainability performance and transparency can become observable in the sustainability ratings of data providers, which are increasingly used in investment decisions and academic research (Fiaschi et al., 2020).

This paper examines the public, external effect of incident-driven private engagement dialogs in the form of publicly disclosed financial and non-financial measurements that are available to broader stakeholders, in addition to the institutional investors who are involved in the initial private dialogs. The large-scale empirical studies to date provide evidence of the effects of thematic private engagements targeting domestic companies with the aim of improving financial performance by making changes in sustainability practices (Barko et al., 2018; Bauer et al., 2014; Dimson et al., 2015; Hoepner et al., 2018). Assuming the economic perspective, broad-scale studies have shown that private thematic dialogs improve accounting performance and governance (Dimson et al., 2015), sales growth and portfolio returns (Barko et al., 2018), and reduced downside risks (Hoepner et al., 2018). Thematic activism also increases the sustainability ratings of target companies with ex ante low sustainability scores (Barko et al., 2018). From interviews with UK institutional investors, qualitative studies have claimed that private sustainability reporting (i.e., private meetings between institutional investors and investees) tends to inform and supplement public sustainability reporting, have a proactive nature, and merge with private financial reporting (Atkins et al., 2015; Solomon et al., 2011). Another stream of the empirical literature has shown that the initiation of voluntary disclosure of sustainability activities positively correlates with ESG performance ratings (Dhaliwal et al., 2011). Sustainability reporting can be transformative and can elicit changes in company practices (Solomon et al., 2011). This paper focuses on the initiation of specific private, incident-based reporting used by active Nordic institutional investors to present the results of engagement dialog cases in records that include information, such as the dialog goal, the investor action plan, and the suggested improvements in company management due to the risks connected with the incident. The paper extends prior studies by considering the incident-based objectives for private sustainability reporting, by targeting global companies, and by showing the Nordic approach to investor activism.

This paper uses unique, proprietary data from the private reports of engagement dialog cases between Nordic institutional investors and public companies related to detected sustainability incidents that constitute a potential material risk for those investors. Sustainability risk incidents reveal single or systematic failure of companies to comply with social norms, such as the United Nations Global Compact principles. To manage potential material risk exposure, a professional agent - acting on behalf of the Nordic institutional investors targeting the company-initiates a dialog process with the company responsible for the risk incident to propose and discuss changes in the company's sustainability policies and performance on a collaborative engagement platform with the invited shareholders. The private dialog case reports are created when the initial analysis of the target company determines that active engagement dialog should be pursued. This paper employs 326 private reports of sustainability dialogs between a professional agent for Nordic institutional investors and 267 MSCI World Index publicly traded companies from 2005 through 2013. Building on legitimacy theory, this paper first descriptively analyzes a sample of incident-based private reports with a focus on sustainability incidents and improvements for the target companies. Second, the paper empirically examines whether incident-based private reports are associated with a decline in the market value and sustainability performance of the target companies in the year following the initiation of the private disclosure relative to the MSCI World Index average. Third, the paper provides evidence as to whether the initiation of incident-based private reporting in engagement dialogs with public companies has a visible impact on the sustainability performance, sustainability transparency, and financial performance of target companies in the 3 years following compared with a matched control group of companies.

In brief, the findings are as follows. Descriptively, the paper shows that private sustainability reporting is dominated by the improvements relating to the areas of social incidents, such as human rights, labor standards, child labor and workplace health and safety. The number of private sustainability reports increase during the sample period. The 
empirical results document that incident-based private sustainability reporting decreases the market value and sustainability rating of the target companies in the next year relative to the universal portfolio of publicly traded MSCI World Index companies. After using a matched group of non-target companies with similar characteristics in terms of their size, market value, sustainability performance, industry and country, the paper finds that private sustainability reporting does not affect sustainability performance and transparency ratings and financial performance in the 3 years after the initiation of private information exchange between institutional investors and target companies. In sum, the results indicate that private sustainability information is not reflected in a public disclosure system of target listed companies when measuring their financial and non-financial performance and transparency.

The remainder of the paper is organized as follows. "Theory" section provides the theoretical framework for this study, and then "Related Literature" section presents the relevant prior literature on active ownership. "Methodology" section describes the data. "Model and Results" section presents the empirical evidence of the financial and nonfinancial effects of active sustainability engagement before concluding the paper.

\section{Theory}

Private reporting and engagement dialog on sustainability issues is a sustainable and responsible investment (SRI) strategy adopted by Nordic institutional investors practicing active ownership. The principles for responsible investment (PRI) initiative, which focuses on asset owners and asset managers who incorporate environmental and social risks into their investment decisions, defines sustainability engagement as "interactions between the investor and current or potential investees (which may be companies, governments, municipalities, etc.) on environmental, social and governance (ESG) issues. Engagements are undertaken to influence (or identify the need to influence) ESG practices and/or improve ESG disclosure" (PRI, 2018, p. 8). Private reporting on sustainability issues evolves in response to a need to extend company visibility and accountability and represents a potentially powerful corporate governance mechanism used in the sustainability domain (Solomon et al., 2013).

Legitimacy theory has been a highly influential theoretical perspective in accounting research to explore companies' responses to social pressures from investors, in particular through the use of public sustainability disclosures (Aerts \& Cormier, 2009; Blanc et al., 2017; Deegan et al., 2002). Most of the prior studies explicitly examined the impact of media pressure on public disclosure of sustainability performance
(Blanc et al., 2017; Brown \& Deegan, 1998; Deegan et al., 2000, 2002; Islam \& Deegan, 2010; Patten, 2002). Prior evidence has demonstrated that greater media pressure leads to higher levels of publicly reported sustainability disclosures. Legitimacy theory states that companies continually seek to ensure that they operate within social norms and are responsive to social expectations and demands (Deegan, 2014). An unexpected sustainability incident creates a legitimacy gap when the news media reports previously unknown information about a company's breach of social norms. Failure to comply with social norms threatens the legitimacy of the company and can lead to sanctions being imposed by society (such as compliance costs, increased taxes, reduction of consumer demand for products, lower stock prices, and threatened company reputation) and exposure to higher financial risk in the long run (Deegan, 2014; Solomon et al., 2013). To solve the legitimacy problems after a legitimacy-threatening incident, legitimacy theory predicts that companies can enhance company transparency and sustainability disclosure (Deegan, 2014). This paper therefore proposes that companies are likely to be willing to repair lost legitimacy and respond to the private pressures and recommendations arising from institutional investors in relation to a sustainability incident. For example, a legitimation strategy within the target company can increase the extent of public disclosure of sustainability performance information and improve product quality and safety standards. Consequently, the provision of sustainability disclosures using private reporting can be influenced by a legitimization sustainability strategy from the public company responding to private pressure from institutional investors.

Legitimacy theory further argues that a company can attempt, when it responds to investors' incident-driven social demands, to provide information through public disclosure about changes in the company's sustainability performance (Deegan, 2014). The assumption of legitimacy theory is that companies facing legitimacy threats would provide disclosures and align performance and actions (or operations) to broader societal expectations and values. As a legitimizing effect of private reporting, companies can improve their publicly disclosed measurements of sustainability performance and transparency to bring company behavior into line with the values and expectations of broader SRI investors and society (Deegan, 2014).

Legitimacy theory also asserts that a company's legitimacy strategy can provide financial benefits arising from complying with social expectations and from the "business case." Companies with sustainable performance records can obtain the necessary resources to continue operations and reduce costs due to process innovation (Clarkson et al., 2013; Deegan, 2014). The market positively values public disclosures providing new information about sustainability performance improvements and activities (Clarkson et al., 
2004, 2013; Dhaliwal et al., 2011). In particular, transparent sustainability disclosures provide valuation-relevant information for predicting financial performance. Changes in the companies' sustainability performance resulting from public pressures and private dialogs can improve operational efficiency and affect operational performance (Clarkson et al., 2013; Solomon \& Darby, 2005; Solomon et al., 2013). This paper thus argues that incident-based private sustainability reporting in engagement dialogs with public companies is likely to be associated with subsequent improvements in publicly disclosed measurements of target companies, such as level of sustainability performance and transparency, market valuation, and operating performance.

\section{Related Literature}

This paper employs legitimacy theory to answer the following research question:

RQ Does incident-driven private sustainability reporting in engagement dialogs with public companies improve the publicly disclosed measurements of target company financial and non-financial performance and transparency?

The empirical evidence on the public effects of private reporting remains limited, because the data on private engagement dialogs are not usually made public. Focusing on incident-based private reporting, this paper seeks to contribute to several strands of existing research. First, this study is related to the large-scale studies by Dimson et al. (2015), Barko et al. (2018), and Hoepner et al. (2018), which analyzed the outcomes of private thematic engagement on sustainability issues. These studies examined private ESG engagements conducted by a stand-alone large institutional investor for US or UK public companies to increase the financial returns of investee companies by improving their low sustainability performance. They found that target companies responded to the demands of the institutional investor and made satisfactory changes in their business practices. Dimson et al. (2015) reported that private thematic engagements were associated with positive abnormal returns over the year following the initial engagement. The results also documented improvements in the target companies' operating performance, sales, employee efficiency, stock volatility, and governance. Hoepner et al. (2018) showed that thematic engagement reduced downside risk and created value for a large institutional investor. Barko et al. (2018) found that private thematic engagements increased the sales growth, financial return, and sustainability ratings of target companies with the lowest ex ante sustainability ratings, but did not change their profitability. The current paper differs from these three studies because it only considers incident-based private reporting in engagement dialogs. It also analyzes global target companies and the public effects of private reporting as reflected in the performance and transparency ratings of ESG data providers, which are available to broader stakeholders.

There is a small but growing literature devoted to private sustainability reporting in engagement dialogs with public companies (Atkins et al., 2015; Solomon \& Darby, 2005; Solomon \& Solomon, 2006; Solomon et al., 2013). Based on interviews with UK institutional investors engaged in one-on-one meetings with investees on social and environmental issues, studies have suggested that these investors supplement inadequate public sustainability reporting by the development of sophisticated private disclosures (Solomon \& Solomon, 2006). Solomon et al. (2011) documented that the nature of private climate change reporting reflected a discourse of risk and risk management and an emerging discourse of material opportunities for the investee companies to exploit. Solomon and Solomon (2006), Atkins et al. (2015), and Solomon et al. (2011) emphasized the dialogic nature of the private sustainability reporting process. Atkins et al. (2015) provided evidence for the emergence of integrated private reporting as a merging of private sustainability reporting with private financial reporting. However, there are some studies that have argued the outcomes of the private reporting process can be uncertain (Solomon \& Darby, 2005; Solomon et al., 2013). Studies have recognized a potential for private sustainability reporting to enhance accountability but interpret their findings as a lack of actual change in company behavior on sustainability issues. This paper analyzes specialized case reports used by institutional investors to summarize the details applied to the dialog with the investee company, but does not use interviews to derive data on private sustainability reporting.

This paper is related to the growing literature on the effects of shareholder resolutions on sustainability issues. Prior research reports that shareholder resolutions on sustainability concerns are often withdrawn due to satisfactory private negotiations with company management (Bauer et al., 2015). The empirical results on the effects of shareholder resolutions on financial and sustainability performance and disclosure of companies have been mixed. David et al. (2007) showed that shareholder resolutions reduced subsequent corporate social performance (CSP) and lead companies to divert resources from CSP into political activities used to respond to the pressures of social investors. Although the study found that companies achieved agreements with shareholders, the decrease in the CSP rating for withdrawn resolutions indicates that companies used symbolic responses to shareholder pressure and resisted making substantial changes in their CSP. Vasi and King (2012) documented the influence of shareholder resolutions about environmental issues on the perceived environmental risk of target companies, referring to potential 
financial threats for environmental failure or crisis due to the poor environmental practices and policies of the target companies, which subsequently had a negative effect on their financial performance. Barber (2007) examined the activism by the pension fund CalPERS, which focused on a mixed range of issues, including corporate governance (traditional topics), greenhouse gas emissions, fuel efficiency, labor negotiations, and investment in tobacco companies, Sudan, and South Africa. CalPERS made public announcements about the target companies (focus list), which yielded positive market reactions on the announcement date. This study provides support for this idea that shareholder proposals about shareholder rights improve market value in the short and long run, while activism on sustainability issues has no link to market value and is implemented due to the moral concerns of institutional investors.

In contrast, Reid and Toffel (2009) found a positive outcome for active ownership. Submitted shareholder resolutions on environmental issues (e.g., climate change, environmental disclosure, emissions reduction, and renewable energy) influenced the decision of target companies to publicly disclose environmental information to the Carbon Disclosure Project. A recent study by Grewal et al. (2016) found that filing a shareholder resolution on sustainability issues was related to subsequent improvements in the performance of the company on the focal sustainability issue, and resolutions on material sustainability issues were associated with subsequent increases in the market value of the company. The present paper differs from these two studies because it focuses on private reporting that takes place in engagement dialogs on sustainability improvements between the agent for institutional investors and investee companies prior to or independent of shareholder resolutions.

This study also adopts the Nordic perspective of SRI activism, while prior research on shareholder resolutions has been framed by the Anglo-Saxon corporate governance perspective. The Nordic stakeholder-oriented corporate governance model is characterized by active, long-term ownership, consensus-seeking dialog, stakeholder value creation, employee representation at the board level, and transparency (Poulsen et al., 2010; Thomsen \& Conyon, 2012). The Anglo-Saxon corporate governance model includes marketoriented and shareholder-centric elements, dispersed ownership, and shareholder value maximization, and relies on more formal public means of activism through shareholder resolutions (Thomsen \& Conyon, 2012).

This study is related to the extensive literature studying the financial outcomes of active ownership on corporate governance topics (Bauer et al., 2015; Becht et al., 2009; Carleton et al., 1998; Rehbein et al., 2013). In this stream of research, Carleton et al. (1998) analyzed private negotiations between the financial institution, TIAA-CREF, and US target companies, which were initiated simultaneously with the filing of shareholder resolutions. They documented that public announcements of targeting were associated with abnormal returns. However, no significant increases were found in the accounting measures of company performance in relation to changes made in company governance practices requested by TIAA-CREF. Becht et al. (2009) examined private engagements by the activist fund Hermes in the UK, which sought to change the corporate governance structure of target underperforming companies. They provided insignificant evidence of increases in return on assets 2 years after the complete engagement. The hypothesis of the present paper is that incident-based private reporting in engagement dialogs with public companies on sustainability improvements has visible effects on target companies' publicly disclosed measures of financial and non-financial performance and transparency.

\section{Methodology}

\section{Data}

The proprietary data have been provided for academic research by a professional agent specializing in SRI. This agent has provided Nordic institutional investors, who take a long-term and active approach to their ownership, with an assessment of company sustainability risks and opportunities. In 2005, the agent established the Engagement Forum, a collaborative platform for an active ownership process; it is a transparent platform where institutional investors follow the systematic dialog process with specified goals and have a real-time view on the development of the process through an online interface. Nordic institutional investors can make individual and collaborative decisions to target a specific company. The Engagement Forum is based on a systematic screening of companies in terms of their compliance with international norms-such as the UN Global Compact and the OECD Guidelines for Multinational Enterprises-on sustainability issues. Alleged violations of sustainability norms in the form of sustainability incidents come from the agent's Alert Service database, which selects publicly reported news of special concern to investors. Sustainability incidents with engagement potential are investigated by analysts who decide whether the incident represents a dialog case for the Engagement Forum. On behalf of investors, the agent enters into a direct, constructive dialog process with the criticized company to ensure that the company accepts responsibility for compliance with sustainability norms and takes appropriate and verifiable actions to correct the reported violation and avoid similar incidents in the future. This process consists of a sequence of interactions such as letters, emails, faxing, phone calls, conference calls, and face-to-face meetings at operational, management, and board levels. From the proprietary Engagement Forum database, this study obtained records on 
private reports, the companies' identifiers, and sustainability risk ratings. This database is used by the agent's clients involved in the active ownership process and assesses a company's sustainability risks and opportunities.

Sustainability performance ratings retrieved from the agent's proprietary Risk Rating database reflect a company's ability and preparedness to handle company-specific risks. Sustainability performance ratings are based on a numerical scale ranging from zero (bad performance) to six (good performance). Examples of environmental indicators include environmental policy and targets, environmental management system, environmental certification, use of renewable energy sources, and recycling of products or equipment. Social indicators reflect the management of relationships with employees, communities, and suppliers. Governance indicators reflect board management and control, shareholder rights, and transparency and incentives. This study used the total sustainability performance score. The sustainability performance ratings are made available for academic research for the period 2003-2013.

This study also obtained annual assessments of sustainability performance and transparency from Thomson Reuters ASSET4 rating database over the period 2002-2016. Ratings are based on a numerical scale ranging from $100 \%$ (good performance) to $0 \%$ (poor performance). The total sustainability performance rating is based on environmental, social, and corporate governance indicators. The sustainability transparency rating is based on the integration/vision and strategy category, which reflects a company's capacity to convincingly demonstrate and communicate the integration of sustainability dimensions into company activities and processes. The sustainability transparency rating includes publication of sustainability information in specific reports, publication of a yearly Global Reporting Initiative (GRI) Report, provision of assurance on sustainability disclosures, policy for communicating transparently on sustainability issues, and integration of sustainability factors in the annual report- to name only the material dimensions of the transparency rating. To distinguish between the sustainability performance ratings obtained from different databases, this paper codes those from the Thomson Reuters database as TRPERF and those from the agent's Risk Rating database as APERF.

\section{Private Sustainability Reports}

Private sustainability reports relate to an engagement dialog case-also called an incident-on which the analysis is performed. Private sustainability reports include, among other elements, information on the case identification number, target company, reported incident, location of incident, news that serves as the foundation for the case, the social norms violated by the company, summary of the case, characteristics of the dialog process, recommendations and data points. For example, an incident deals with a company association with child labor in cocoa harvesting; a suit filed against the company alleges company involvement in the trafficking, torture, and forced labor of children who cultivate and harvest cocoa beans. The International Labor Rights Fund claims that children were forced to work 12-14 h a day with no pay, little food and sleep, and frequent beatings. The reported incident is associated with a violation of the UN Global Compact Principle 5 addressing child labor and the corresponding Guideline $\mathrm{V}$ of the OECD Guidelines for Multinational Enterprises. The target company provides information relating to its efforts to combat child labor in its supply chain, and this information includes own farmer programs, membership in the program carried out by the World Cocoa Foundation, a supplier code, and audits on compliance at some suppliers. The recommended improvements of company sustainability practices relate to addressing labor rights, including child labor in corporate policies, and demonstrating how these policies will be enforced with programs to ensure compliance with the standards in its cocoa supply chain. The target company needs to demonstrate and report on a regular basis about how the company is working to increase the purchase of certified cocoa. There is also a recommendation to develop supplier guidelines for high-risk commodities, such as cocoa, and increase the amount of products certified according to Fair Trade. Another private report relates to a company's association with water pollution that is causing health problems, environmental damage, safety negligence at manufacturing plants, labor rights violation in the supply chain, and bribery. The recommended changes include, among other activities, the development of an environmental and social impact assessment of investment projects, improvement of the labor rights requirement from company suppliers and contractors, adoption of a corporate policy and routines to address environmental and social risks, and improvement of transparency in how a company manages environmental and social issues.

\section{Sample}

The sample in this paper included 373 private reports. After aggregation of the private reports with Thomson Reuters's data on company characteristics by company ISIN code and name, we were left with 326 private reports for the period from 2005 to 2013.

Table 1, Panel A shows the distribution of incident-related private reports across areas of sustainability improvements applying to the report. During the period 2005-2013, the area of human rights improvements had the largest proportion of reports $(40.18 \%)$, followed by labor rights (31.60\%), and the environment (20.86\%). Finally, the private reports on corruption have the lowest proportion of cases (7.36\%). Table 1, Panel B presents the distribution of private reports by year. There is an increasing trend in the number of reports 
Table 1 Summary of private reports

Panel A: distribution of reports across areas of proposed improvements

\begin{tabular}{|c|c|c|c|c|c|c|}
\hline \multicolumn{3}{|l|}{ Improvement area } & \multicolumn{3}{|l|}{ Num. of reports } & \multirow{2}{*}{$\frac{\% \text { of sample }}{20.86}$} \\
\hline Environment & & & 68 & & & \\
\hline Human rights & & & 131 & & & 40.18 \\
\hline Labor rights & & & 103 & & & 31.60 \\
\hline Corruption & & & 24 & & & 7.36 \\
\hline Total & & & 326 & & & 100.0 \\
\hline \multicolumn{7}{|c|}{ Panel B: distribution of reports across years } \\
\hline Engagement year & Num. of reports & $\%$ of sample & Environment & Human rights & Labor rights & Corruption \\
\hline 2005 & 17 & 5.21 & 2 & 5 & 10 & 0 \\
\hline 2006 & 35 & 10.74 & 9 & 11 & 8 & 7 \\
\hline 2007 & 12 & 3.68 & 4 & 5 & 1 & 2 \\
\hline 2008 & 8 & 2.45 & 3 & 4 & 0 & 1 \\
\hline 2009 & 50 & 15.34 & 15 & 28 & 7 & 0 \\
\hline 2010 & 45 & 13.80 & 5 & 17 & 21 & 2 \\
\hline 2011 & 79 & 24.23 & 19 & 30 & 26 & 4 \\
\hline 2012 & 79 & 24.23 & 11 & 31 & 29 & 8 \\
\hline 2013 & 1 & 0.31 & 0 & 0 & 1 & 0 \\
\hline Total & 326 & 100.0 & 68 & 131 & 103 & 24 \\
\hline
\end{tabular}

Panel C: distribution of reports across industries

\begin{tabular}{|c|c|c|c|c|c|c|}
\hline Industry name & Num. of reports & $\%$ of sample & Environment & Human rights & Labor rights & Corruption \\
\hline Basic materials & 64 & 19.63 & 23 & 27 & 13 & 1 \\
\hline Consumer goods & 51 & 15.64 & 11 & 9 & 28 & 3 \\
\hline Consumer services & 42 & 12.88 & 4 & 6 & 26 & 6 \\
\hline Financials & 26 & 7.98 & 2 & 19 & 4 & 1 \\
\hline Health care & 3 & 0.92 & 0 & 2 & 1 & 0 \\
\hline Industrials & 57 & 17.48 & 10 & 28 & 13 & 6 \\
\hline Oil and gas & 44 & 13.50 & 16 & 14 & 10 & 4 \\
\hline Technology & 21 & 6.44 & 0 & 16 & 4 & 1 \\
\hline Telecommunications & 8 & 2.45 & 0 & 3 & 3 & 2 \\
\hline Utilities & 10 & 3.07 & 2 & 7 & 1 & 0 \\
\hline Total & 326 & 100.0 & 68 & 131 & 103 & 24 \\
\hline \multicolumn{7}{|c|}{ Panel D: distribution of reports across geographical areas } \\
\hline Country group & Num. of reports & $\%$ of sample & Environment & Human rights & Labor rights & Corruption \\
\hline Africa & 5 & 1.53 & 1 & 3 & 1 & 0 \\
\hline Americas & 123 & 37.73 & 20 & 52 & 40 & 11 \\
\hline Asia & 81 & 24.85 & 26 & 28 & 24 & 3 \\
\hline Australasia & 11 & 3.37 & 3 & 6 & 1 & 1 \\
\hline Europe & 106 & 32.52 & 18 & 42 & 37 & 9 \\
\hline Total & 326 & 100.0 & 68 & 131 & 103 & 24 \\
\hline
\end{tabular}

over time from 17 reports in 2005 to 79 reports in 2012. In 2007 and 2008, the number of reports is small, 12 and 8 reports, respectively. Table 1 , Panel $\mathrm{C}$ shows the sector distribution based on ICB industry classifications. The Basic Materials sector constitutes $19.63 \%$ of the reports and is followed by the Industrial sector with $17.48 \%$ of the reports and the Consumer Goods sector with $15.64 \%$ of the reports. The Health Care and Telecommunications sectors have the lowest proportion of reports $(0.92 \%$ and $2.45 \%$, respectively). Table 1 , Panel $\mathrm{D}$ documents the distribution of reports across geographical areas. The Americas and Europe 
have the largest proportions of reports $(39.7 \%$ and $31.5 \%$, respectively).

\section{Model and Results}

\section{Effect of Private Sustainability Disclosures}

This paper uses two approaches to examine the effect that private sustainability reporting in engagement dialogs with public companies has on target companies' publicly disclosed measurements in the form of sustainability performance and transparency ratings, market valuation, and operating performance. Following Dhaliwal et al. (2011), the first approach relates the financial and sustainability characteristics of the companies hit by incidents to an average MSCI World Index company and presents empirical regression models of private disclosures on the change in company performance and transparency. The second approach estimates the effect of private sustainability reporting by comparing the characteristics of target companies with the most similar companies that are not targeted for an engagement dialog, using the propensity score matching method developed by Shipman et al. (2017) to estimate the average treatment effects of private dialog on a target company's external performance and transparency. To test whether target companies experience changes in company performance and disclosure ratings in the next year following the initiation of private disclosure, the paper estimates the regression models specified below:

$$
\begin{aligned}
& \triangle P E R F_{i, t+1}=b_{0}+b_{1} R E P_{i, t}+b_{2} \Delta \operatorname{SIZE}_{i, t}+b_{3} \Delta L E V E R A G E_{i, t} \\
& +b_{4} \Delta R O A_{i, t}+b_{5} \Delta C A P E X_{i, t} \\
& \text { + INDUSTRY INDICATORS + TIME INDICATORS } \\
& + \text { COUNTRY INDICATORS }+\varepsilon_{i} \\
& \triangle \operatorname{TRANSP}_{i, t+1}=b_{0}+b_{1} R E P_{i, t}+b_{2} \Delta S I Z E_{i, t} \\
& +b_{3} \Delta L E V E R A G E_{i, t}+b \triangle R O A_{i, t} \\
& +b_{5} \triangle \text { CAPEX }_{i, t}+\text { INDUSTRY EFFECTS } \\
& + \text { TIME EFFECTS + COUNTRY EFFECTS }+\varepsilon_{i}
\end{aligned}
$$

$$
\begin{aligned}
\Delta \text { ROA }_{i, t+1} & =b_{0}+b_{1} \text { REP }_{i, t}+b_{2} \Delta \text { SIZE }_{i, t}+b_{3} \Delta \text { LEVERAGE }_{i, t} \\
& +b_{4} \Delta \text { CAPEX }_{i, t}+b_{5} \Delta A G E_{i, t}+b_{6} \Delta \text { GROWTH }_{i, t} \\
& +b_{7} \Delta \text { DIVR }_{i, t}+\text { INDUSTRY EFFECTS } \\
& + \text { TIME EFFECTS }^{\text {TIMUNTRY EFFECTS }}+\varepsilon_{i}
\end{aligned}
$$

$$
\begin{aligned}
& \triangle \text { TOBINQ }_{i, t+1}=b_{0}+b_{1} \text { REP }_{i, t}+b_{2} \Delta \text { SIZE }_{i, t}+b_{3} \Delta \text { GROWTH }_{i, t} \\
& +b_{4} \Delta R O A_{i, t}+b_{5} \Delta C A P E X_{i, t}+b_{6} \Delta A G E_{i, t} \\
& +b_{7} \Delta D I V R_{i, t}+\text { INDUSTRY EFFECTS } \\
& + \text { TIME EFFECTS + COUNTRY EFFECTS }+\varepsilon_{i}
\end{aligned}
$$

where $\triangle P E R F_{i, t+1}, \triangle T R A N S P_{i, t+1}, \Delta R O A_{i, t+1}, \Delta Q_{i, t+1}$ are the change in sustainability performance, sustainability transparency, operating performance, and market value from year $t$ to year $t+1$, following Dhaliwal et al. (2011). $R E P_{i t}$ is an indicator variable that equals one if company $i$ is engaged in private reporting in year $t$, and zero otherwise, following the approach of Brav et al. (2008) and Dhaliwal et al. (2011). The control variables adopt the change form.

This study includes control variables based on the extant literature. Clarkson et al. (2011) and Dhaliwal et al. (2011) argue that ROA is positively associated with company sustainability performance because companies with good financial performance are likely to have more resources to practice sustainability activities and produce sustainability reports. Guenster et al. (2011) have shown that ROA is positively associated with Tobin's $Q$. The regression model therefore includes ROA. This study also controls for size, which is associated with various factors driving companies to invest in sustainability activities and improve sustainability transparency, such as public pressure or financial resources, as Dhaliwal et al. (2011) and Clarkson et al. (2011) have documented that company size is positively associated with sustainability performance and disclosure. Guenster et al. (2011) found that company size was negatively associated with ROA and Tobin's $Q$. This study therefore includes company size measured as the natural logarithm of total assets. Following Grewal et al. (2016) and Clarkson et al. (2011), the model includes the ratio of capital expenditure defined as capital expenditures divided by total assets. Companies with higher capital expenditures are expected to have newer equipment and technologies (Clarkson et al., 2011). The leverage ratio is included to control for financial risk (Guenster et al., 2011). Guenster et al. (2011) found that sales growth and company age correlated with company financial performance: sales growth was positively associated with Tobin's $Q$, and company age was negatively associated with Tobin's $Q$, although according to Bebchuk et al. (2015), company age is positively associated with ROA. The regression model therefore includes sales growth and company age. Finally, dividend divided by book value of equity is positively associated with market value and operating performance.

Endogeneity and self-selection can potentially affect empirical results. In the main analysis, this study used a lead-lag approach to tackle these issues, following Dhaliwal et al. (2011); we also conducted the Lagrangian multiplier (LM) test to identify the presence of endogeneity. To 
Table 2 Private sustainability reporting and company performance: Full sample of MSCI World Index companies

Panel A: descriptive statistics

Variable Full sample $R E P_{t}=1$

$p$ value (differ-

ence)

\begin{tabular}{|c|c|c|c|c|}
\hline$\triangle T R P E R F_{t+1}$ & 0.1391 & 0.0977 & 0.1447 & 0.0001 \\
\hline$\triangle A P E R F_{t+1}$ & 0.3542 & 0.2301 & 0.3736 & 0.0000 \\
\hline$\Delta T R A N S P_{t+1}$ & 0.1163 & 0.1052 & 0.1178 & 0.2775 \\
\hline$\Delta R O A_{t+1}$ & -4.2601 & -4.5587 & -4.2114 & 0.5593 \\
\hline$\Delta Q_{t+1}$ & 0.3398 & 0.3250 & 0.3422 & 0.7861 \\
\hline$\Delta S I Z E_{t}$ & 0.0039 & 0.0045 & 0.0038 & 0.0022 \\
\hline$\triangle L E V E R A G E_{t}$ & 1.7302 & 1.3087 & 1.7990 & 0.1804 \\
\hline$\triangle C A P E X_{t}$ & 0.7614 & 0.2248 & 0.8485 & 0.4338 \\
\hline$\Delta A G E_{t}$ & 0.0864 & 0.0970 & 0.0848 & 0.0000 \\
\hline$\triangle G R O W T H_{t}$ & -0.6882 & 0.0156 & -0.8022 & 0.1686 \\
\hline$\Delta D I V R_{t}$ & 3.7228 & 0.9913 & 4.1817 & 0.6378 \\
\hline
\end{tabular}

Panel B: effects of private sustainability reporting: full sample of MSCI World Index companies

\begin{tabular}{|c|c|c|c|c|c|}
\hline Variable & $\triangle T R P E R F_{t+1}$ & $\triangle A P E R F_{t+1}$ & $\Delta T R A N S P_{t+1}$ & $\Delta R O A_{t+1}$ & $\Delta Q_{t+1}$ \\
\hline$R E P_{t}$ & $0.0169(0.456)$ & $-0.0900(0.008)$ & $0.0224(0.479)$ & $-2.5797(0.351)$ & $-0.2439(0.000)$ \\
\hline$\Delta S I Z E_{t}$ & $1.1055(0.002)$ & $4.4576(0.000)$ & $0.7016(0.041)$ & $144.819(0.000)$ & $-3.6847(0.006)$ \\
\hline$\triangle L E V E R A G E_{t}$ & $0.0001(0.728)$ & $0.0007(0.245)$ & $-0.0002(0.408)$ & $-0.0134(0.364)$ & \\
\hline$\triangle C A P E X_{t}$ & $-0.0000(0.132)$ & $-0.0011(0.003)$ & $-0.0001(0.140)$ & $0.0005(0.483)$ & $-0.0001(0.295)$ \\
\hline$\triangle R O A_{t}$ & $-0.0001(0.636)$ & $-0.0001(0.764)$ & $-0.0003(0.180)$ & & $-0.0003(0.761)$ \\
\hline$\triangle A G E_{t}$ & & & & $-5.3471(0.045)$ & $0.3221(0.029)$ \\
\hline$\Delta G R O W T H_{t}$ & & & & $-0.0037(0.366)$ & $-0.0001(0.546)$ \\
\hline$\Delta D I V R_{t}$ & & & & $-0.0000(0.489)$ & $0.0000(0.978)$ \\
\hline Industry Ind & Yes & Yes & Yes & Yes & Yes \\
\hline Time Ind & Yes & Yes & Yes & Yes & Yes \\
\hline Country Ind & Yes & Yes & Yes & Yes & Yes \\
\hline Adjusted $R^{2}$ & 0.0247 & 0.5345 & 0.0088 & 0.0145 & 0.0079 \\
\hline Num. of obs. & 19,643 & 10,254 & 19,643 & 18,207 & 18,270 \\
\hline
\end{tabular}

Parameter estimates are reported with their $p$ values (2-sided) in parentheses. Standard errors are clustered at the company level. Significance at $p \leq 0.10$ is highlighted in bold. All continuous variables are winsorized at the 1 st and 99th percentiles. REP is indicator variable that equals 1 if company $i$ is engaged in the initiation of private sustainability reporting in year $t$, and 0 otherwise

further enhance inferences based on the empirical approach, this study adopted the Heckman two-stage procedure and repeated our main tests. The Heckman two-stage procedure introduces the inverse Mills ratio into the second-stage OLS regression to control for the self-selection bias related to private engagement. This allowed us to take into account potential endogeneity when there was a correlation between the independent variables and the error term in the empirical model. We followed the prior literature and used industryadjusted measures of Tobin's $Q$, ROA, sustainability performance, and sustainability transparency (Dhaliwal et al., 2011; Grewal et al., 2016). Grewal et al. (2016) argued that adjusting for industry median effectively controls for timevarying changes in industry sustainability performance and market valuation. They stated that industry-adjusted measures neutralize the effect of specific industries. We therefore adjusted measures of Tobin's $Q$, ROA, sustainability performance, and sustainability transparency each year by industry medians to determine relative performance and disclosure scores. We also adopted the approach of Clarkson et al. (2011) and considered changes over a 2-year period, measuring the change in sustainability performance, sustainability transparency, operating performance, and market value from year $t$ to year $t+2$. Finally, we included an R\&D ratio, defined as R\&D expenditure divided by total assets.

Table 2, Panel A shows the descriptive statistics and univariate tests for the full sample of MSCI World Index companies divided into two groups: target and non-target companies. Non-target companies had higher changes in sustainability performance ratings for Thomson Reuters and the agent in the subsequent year compared to target companies. In particular, changes in sustainability ratings by Thomson 
Reuters were significantly lower for target companies in the following year after being targeted in relation to a sustainability incident.

Table 2, Panel B presents the regression results comparing the financial and sustainability characteristics of target companies to non-target companies in the MSCI World Index. Private sustainability reporting, REP, is significantly negatively associated with an APERF change in sustainability performance rating, while it is insignificantly associated with a TRPERF change in sustainability performance. There appears to be no evidence that private reporting, REP, is associated with a change in sustainability transparency, TRANSP. Furthermore, private reporting, REP, is significantly negatively associated with change in market value, $Q$. However, the coefficient between REP and change in ROA is insignificant.

Finally, we examined the robustness of the results. For each regression model, we conducted the LM test to identify the presence of endogeneity; the results were not significant and endogeneity does not qualitatively impact the main results. The coefficients on REP from the Heckman two-stage treatment effect models are consistent with the main results. When industry-adjusted dependent variables are used and an additional control variable, the $\mathrm{R} \& \mathrm{D}$ ratio, is included in the regression models, the main results do not change (not reported).

The second set of tests is based on the matching technique to estimate the effect of private disclosure on company external performance and disclosure ratings. The matching method has previously been used by, for example Dimson et al. (2015) and Brav et al. (2008), who constructed a matched sample using matching criteria of year, industry, and mark-to-book ratio. In Carleton et al. (1998) and Smith (1996), a matched sample of non-target companies is based on matching criteria of size and industry. Del Guercio and Hawkins (1999) matched companies in terms of accounting performance, market capitalization, and two-digit industry codes to examine the impact of activism on operating performance.

This study followed the approach of Grewal et al. (2016) and implemented propensity score matching with replacement. For each target company, a matching estimator found the most similar non-target company as determined using the propensity score. This approach was adopted because the matching criteria included continuous variables. Exact matching was used for the year of initiation of private disclosure from a sample of MSCI World Index companies that were not targeted. Consistent with Dimson et al. (2015), the empirical approach matched targeted and control companies one year before the engagement. The functional form of the propensity score was based on company size, market value, sustainability performance, industry indicators, and country indicators. Company size is its market capitalization. Prior
Table 3 Univariate tests: propensity-score-matched sample

\begin{tabular}{lrccc}
\hline Variable & Engaged & Non-engaged & Mean difference & $p$ value \\
\hline LNMV $_{t-1}$ & 9.3968 & 9.5534 & -1.1936 & 0.2331 \\
TRPERF $_{t-1}$ & 74.9352 & 72.5498 & 1.0500 & 0.2942 \\
APERF $_{t-1}$ & 8.3210 & 7.9908 & 0.9498 & 0.3428 \\
ROA $_{t-1}$ & 14.9970 & 15.1411 & -0.1853 & 0.8531 \\
$Q_{t-1}$ & 39.9862 & 41.3509 & -0.7252 & 0.4687 \\
\hline
\end{tabular}

The table reports the $t$ tests for differences in mean for the group of engaged companies (treated) and non-engaged companies (control). Parameter estimates are reported with their $p$ values (2-sided) in parentheses

research indicates that large companies are more likely to be targeted by activists (Dimson et al., 2015; Smith, 1996). Market value is Tobin's $Q$, which is defined as the sum of the market value of equity and book value of equity, scaled by the sum of the book value of equity and book value of debt. SRI investors are likely to target companies based on market value (Brav et al., 2008; Poulsen et al., 2010). Sustainability performance is the TRPERF rating. Existing studies claim that the concerns of social investors about poor company sustainability performance increase company exposure to activism (Dimson et al., 2015).

Based on the matching approach, this study considered two treatment levels: the company is targeted for engagement and the company is not targeted. For each treatment level, there is a potential outcome. The potential outcomes are company sustainability performance, sustainability transparency, ROA, and $Q$. A treatment effect is the difference in the outcome for companies that experience engagement (treated) and the outcome that results when companies are not engaged (control or nearest). Based on the arguments of Grewal et al. (2016), the propensity score-matching model selected control companies that have very similar levels of sustainability performance, market value, ROA, and size before targeting for dialog. Table 3 presents the average values for the matching variables for target and control groups of companies in the previous year. Out of 326 reports, we found suitable matches for 283 reports. Table 3 shows that none of the differences in matching variables is statistically significant.

Next, we used the empirical models given in Eqs. (1)-(4) and adopted regression analysis of levels. Following Grewal et al. (2016) and Bebchuk et al. (2015), we examined the evolution of outcomes of sustainability engagements over time. Regressions included dummy variables for each of the 3 years following the initiation year- $R E P_{t}, R E P_{t+1}$, $R E P_{t+2}$, and $R E P_{t+3}$; time indicators ranged from $t$ to $t+3$, where $t$ indicates the year that the agent initiates the private report, $t+1$ indicates the year after the agent initiated the private report, $t+2$ indicates 2 years after initiating private reporting, and so on. The study chose a 3 -year window 
Table 4 Effects of private sustainability reporting over time: Propensity-score-matched sample

\begin{tabular}{|c|c|c|c|c|c|}
\hline Variable & TRPERF & $A P E R F$ & TRANSP & $R O A$ & $Q$ \\
\hline$R E P_{t}$ & $-2.1212(0.172)$ & $-0.1138(0.541)$ & $-0.2012(0.913)$ & $-0.3261(0.503)$ & $-0.0341(0.979)$ \\
\hline$R E P_{t+1}$ & $-1.0689(0.457)$ & $-0.4067(0.024)$ & $0.9951(0.548)$ & $-0.4366(0.350)$ & $-1.2533(0.340)$ \\
\hline$R E P_{t+2}$ & $-1.7939(0.565)$ & $-0.2915(0.146)$ & $0.6080(0.711)$ & $-0.0571(0.901)$ & $-0.5875(0.652)$ \\
\hline$R E P_{t+3}$ & $-1.0842(0.404)$ & $-0.1002(0.629)$ & $0.8317(0.589)$ & $-0.8109(0.058)$ & $-1.4263(0.263)$ \\
\hline SIZE & $10.4661(0.000)$ & $1.0395(0.000)$ & $11.2362(0.000)$ & $-0.2543(0.118)$ & $2.3393(0.000)$ \\
\hline LEVERAGE & $-0.0402(0.413)$ & $0.0009(0.876)$ & $-0.0337(0.580)$ & $-0.0816(0.000)$ & \\
\hline CAPEX & $-3.6548(0.000)$ & $-0.3613(0.000)$ & $-2.1638(0.006)$ & $0.4154(0.012)$ & $-0.0975(0.883)$ \\
\hline$A G E$ & & & & $-0.0073(0.728)$ & $-0.2573(0.000)$ \\
\hline GROWTH & & & & $0.1423(0.000)$ & $0.0366(0.224)$ \\
\hline$R O A$ & $0.4666(0.000)$ & $0.03630(0.000)$ & $0.3251(0.001)$ & & $-0.6286(0.000)$ \\
\hline DIVR & & & & $49.7980(0.000)$ & $78.0856(0.000)$ \\
\hline Industry Ind & Yes & Yes & Yes & Yes & Yes \\
\hline Time Ind & Yes & Yes & Yes & Yes & Yes \\
\hline Country Ind & Yes & Yes & Yes & Yes & Yes \\
\hline$R E P_{t-1, t-2, t-3}$ & Yes & Yes & Yes & Yes & Yes \\
\hline Adjusted $R^{2}$ & 0.3937 & 0.6047 & 0.3553 & 0.4213 & 0.2580 \\
\hline Num. of obs. & 5379 & 3517 & 5379 & 6300 & 6261 \\
\hline
\end{tabular}

Parameter estimates are reported with their $\mathrm{p}$ values (2-sided) in parentheses. Standard errors are clustered at the company level. Significance at $p \leq 0.10$ is highlighted in bold. All continuous variables are winsorized at the 1 st and 99 th percentiles

following the initiation of private reporting because complete engagement dialog requires, on average, 3 years of dialog, and prior research has used this period (Del Guercio \& Hawkins, 1999). According to Bebchuk et al. (2015), the coefficients for the private reporting dummies show the difference between the outcome of treatment companies in the year of initiation of private reporting and the next 3 years in relation to matched control companies. The regressions also include private reporting dummies for each of the 3 years before the initiating year to further diminish the influence of pre-engagement trends in dependent variables.

Table 4 presents evidence on the impact of incident-based private disclosure on company sustainability performance, sustainability transparency, operating performance, and market value. We found that, subsequent to the initiation of private reporting, target companies did not experience significant improvements in sustainability transparency rating and market value in the 3 years following an initial targeting. The coefficient for the private disclosure variable at time $t+1$ is significantly negatively associated with the sustainability performance by the agent, APERF, and the private disclosure at time $t+3$ is significantly negatively associated with ROA. Further, we conducted F-tests for the difference between each of the coefficients for $(t+1),(t+2),(t+3)$, and the coefficient of the year $(t-1)$ that proceeds the initiation year. For the sustainability performance dependent variable, APERF, there is a significantly positive difference between the coefficient for $(t+1)$ and the coefficient of the year $(t-1)$. For the ROA regression, the findings show a significantly positive difference between the coefficient for $(t+3)$ and the coefficient of the year $(t-1)$. There is no significant evidence for the other coefficients and variables of outcomes. The results are consistent with those presented in Table 4. Thus, the overall results indicate that the effect of private disclosures on external performance and transparency does not appear to be supported by the data. The insignificant results on the relationships between private reporting and third-party assessments of sustainability performance and transparency do not provide support for the resistance to making changes in sustainability practices (David et al., 2007). The private nature of dialogs can explain the insignificant effects on the publicly disclosed measurements following the initiation of private reporting.

\section{Discussion and Conclusion}

This paper examined the effects of incident-based private sustainability reporting by Nordic institutional investors on target companies' publicly disclosed measurements, such as sustainability performance and transparency ratings, market value, and operating performance. We found that private reports, which take place in hidden dialogs between Nordic institutional investors and their public investee companies, were initiated when Nordic institutional investors believed that there was potential external risk inherent in an unexpected sustainability incident-meaning that a company has breached existing social norms. Private reports and active 
dialogs were initiated when there were specific recommendations of institutional investors for target companies for how the companies are expected to legitimate their sustainability performance and transparency. Private reporting of public companies as an emerging SRI strategy for incidentbased private dialogs differs from the thematic active ownership tactic of prior research, which has an objective to improve financial performance (Atkins et al., 2015; Bauer et al., 2014, 2015; Dimson et al., 2015; Solomon et al., 2011). Previous studies are also restricted to private dialogs driven by a shareholder resolution on ESG topics, which has been a field with poorly performing companies (Bauer et al., 2015; Clark \& Crawford, 2012; Logsdon \& Buren, 2009; Rehbein et al., 2013). This study also sought to extend the academic literature on broader public pressure from the news media on the level of company public sustainability disclosure and performance by focusing on the private pressure of institutional investors.

The theoretical underpinnings for the effects of incidentbased private sustainability reporting on target companies' measurements available to society at large come from the legitimacy theory, which predicts that target companies will respond to the social pressures of institutional investors with higher levels of sustainability disclosure. This paper found that the incident-based social demands of institutional investors targeting specific companies appeared to lead to private sustainability reporting. Using a propensity score matched sample of non-target companies that exhibited similar performance, size, and industry characteristics to that of target companies one year before the initiation, the empirical tests showed that private reporting did not have a significant effect on the sustainability performance, transparency ratings, or financial performance in the 3 years after the initiation of private reporting. In contrast to the studies focusing on the impact of media pressure on the levels of publicly disclosed sustainability performance information, the results indicate that companies facing private threats to their legitimacy can inform the interested parties about sustainability changes through private reporting. However, this study provides no evidence that the companies responding to private demands enhance their public disclosures by reporting on their sustainability changes.

In general, the findings provide support for the argument that companies use private reporting as a legitimizing tool when responding to private pressures. Relative to the average MSCI World Index company, we found that incident-based private reporting was associated with subsequent decreases in market value and the sustainability performance ratings of the target companies. This finding supports the proposition of legitimacy theory that a legitimacy gap in the form of reduced market value occurs when previously unknown information becomes known through a disclosure made within the news media (Deegan, 2014). The findings, however, imply that the effect of incidentbased private sustainability reporting can be difficult to detect through publicly available measurements such as sustainability performance ratings, market value, and operating performance. Overall, it appears that any shortterm positive external effects from private incident-based reporting are difficult to observe from the non-financial sustainability ratings of data providers and company financial performance. For private reporting, the findings present evidence that the equity market is semi-strong-form efficient. The sustainability information needs to be made public in order to determine the market's reaction.

The present paper provides increased recognition and better understanding of active ownership on sustainability issues, especially among SRI institutional investors, company managers, investor advisors, and professional service organizations, such as the UN PRI, the UN GRI, and the UN Global Compact. It also highlights the differences in the engagement approaches of SRI investors. This paper provides evidence for the incident-driven SRI option of private engagement with global companies used by Nordic institutional investors. This study attributes the different findings from prior research (e.g., Dimson et al., 2015; Grewal et al., 2016) to the following research settings: the long-term focus of Nordic institutional investors on risk reduction instead of short-term valuation gains, relatively high pre-engagement levels in target companies' sustainability and financial performance, and narrowly defined private reporting goals and proposed improvements. The results indicate that the outcomes of private pressures through incident-based private dialogs can be difficult to detect via external information such as the sustainability ratings of data providers.

This paper has limitations and can be extended in several ways. The conclusions are relevant for private information exchange between Nordic institutional investors and public companies in the engagement dialogs led by the agent in connection to sustainability incidents. The paper acknowledges the fact that incident-based private reporting can differ between active investors and their agents in other countries and markets. Incident-based private reporting and engagement dialogs on sustainability issues can be offered by other commercial parties and asset managers, particularly in Europe. Furthermore, the paper includes private reports with MSCI World Index publicly traded companies during the period of 2005-2013. The findings of the paper cannot be extended beyond this type of company or to other time periods. Future scholars could examine the particular factors of sustainability engagements supporting active owners in implementing their engagement demands more effectively. Another suggestion would be to identify sustainability 
engagement topics that have high benefits for active owners and other stakeholders in the short and long term.

Funding Open access funding provided by Linnaeus University.

\section{Declarations}

Conflict of interest The authors declare no conflict of interest.

Informed Consent Authors declare no informed consent.

Research Involving Human and Animal Rights Authors declare that research does not involve human participants and animals.

Open Access This article is licensed under a Creative Commons Attribution 4.0 International License, which permits use, sharing, adaptation, distribution and reproduction in any medium or format, as long as you give appropriate credit to the original author(s) and the source, provide a link to the Creative Commons licence, and indicate if changes were made. The images or other third party material in this article are included in the article's Creative Commons licence, unless indicated otherwise in a credit line to the material. If material is not included in the article's Creative Commons licence and your intended use is not permitted by statutory regulation or exceeds the permitted use, you will need to obtain permission directly from the copyright holder. To view a copy of this licence, visit http://creativecommons.org/licenses/by/4.0/.

\section{References}

Aerts, W., \& Cormier, D. (2009). Media legitimacy and corporate environmental communication. Accounting, Organizations and Society, 34(1), 1-27.

Atkins, J., Solomon, A., Joseph, N., \& Norton, S. (2015). The emergence of integrated private reporting. Meditari Accountancy Research, 23(1), 28-61.

Barber, B. (2007). Monitoring the monitor: Evaluating CalPERS' activism. SSRN Working paper. Available at: https://ssrn.com/ abstract $=890321$

Barko, T., Cremers, M., \& Renneboog, L. (2018). Shareholder engagement on Environmental, Social and Governance Performance. Discussion Paper, Tilburg, Center for Economic Research.

Bauer, R., Clark, G. L., \& Viehs, M. (2014). The geography of Shareholder engagement: Evidence from a large British institutional investor. SSRN Working Paper. https://ssrn.com/abstract=22616 49

Bauer, R., Moers, F., \& Viehs, M. (2015). Who withdraws shareholder proposal and does it matter? An analysis of sponsor identity and pay practices. Corporate Governance: An International Review, 23(6), 472-488.

Bebchuk, L., Brav, A., \& Wei, J. (2015). The long-term effects of hedge fund activism. Columbia Law Review, 115, 1085-1156.

Becht, A., Franks, J., Mayer, C., \& Rossi, S. (2009). Returns to shareholder activism: Evidence from a clinical study of the Hermes UK Focus Fund. The Review of Financial Studies, 22(8), 3093-3129.

Blanc, R., Islam, M. A., Patten, D. M., \& Branco, M. C. (2017). Corporate anti-corruption disclosure: An examination of the impact of media exposure and country-level press freedom. Accounting, Auditing \& Accountability Journal, 30(8), 1746-1770.
Brammer, S., \& Pavelin, S. (2006). Corporate reputation and social performance. The importance of fit. Journal of Management Studies, 43(3), 435-455.

Brav, A., Jiang, W., Partnoy, F., \& Thomas, R. (2008). Hedge fund activism, corporate governance, and firm performance. The Journal of Finance, 63, 1729-1775.

Brown, N., \& Deegan, C. (1998). The public disclosure of environmental performance information-a dual test of media agenda setting theory and legitimacy theory. Accounting and Business Research, 29(1), 21-41.

Capelle-Blancard, G., \& Petit, A. (2017). Every little helps? ESG news and stock market reaction. Journal of Business Ethics, 157, 543565. https://doi.org/10.1007/s10551-017-3667-3

Carleton, W., Nelson, J., \& Weisbach, M. (1998). The influence of institutions on corporate governance through private negotiations: Evidence from TIAA-CREF. Journal of Finance, 53(4), 1335-1362.

Clark, C., \& Crawford, P. (2012). Influencing climate change policy: The effect of shareholder pressure and firm environmental performance. Business \& Society, 51(1), 148-175.

Clarkson, P., Fang, X., Li, Y., \& Richardson, G. (2013). The relevance of environmental disclosures: Are such disclosures incrementally informative? Journal of Accounting and Public Policy, 32, 410-431.

Clarkson, P., Li, Y., \& Richardson, G. (2004). The market valuation of environmental expenditures by pulp and paper companies. The Accounting Review, 79, 329-353.

Clarkson, P., Overell, M., \& Chapple, L. (2011). Environmental reporting and its relation to corporate environmental performance. $\mathrm{Aba}$ cus, 47, 27-60.

Cundill, G., Smart, P., \& Wilson, H. (2018). Non-financial shareholder activism: A process model for influencing corporate environmental and social performance. International Journal of Management Reviews, 20, 606-626.

David, P., Bloom, M., \& Hillman, A. (2007). Investor activism, managerial responsiveness, and corporate social performance. Strategic Management Journal, 28, 91-100.

Deegan, C. (2014). Financial accounting theory. McGraw-Hill.

Deegan, C., Rankin, M., \& Tobin, J. (2002). An examination of the corporate social and environmental disclosures of BHP from 1983-1997: A test of legitimacy theory. Accounting, Auditing \& Accountability Journal, 15(3), 312-343.

Deegan, C., Rankin, M., \& Voght, P. (2000). Firms' disclosure reactions to major social incidents: Australian evidence. Accounting Forum, 24(1), 101-130.

Del Guercio, D., \& Hawkins, J. (1999). The motivation and impact of pension fund activism. Journal of FinaNcial Economics, 52(3), 293-340.

Dhaliwal, D., Li, O., Tsang, A., \& Yang, Y. (2011). Voluntary nonfinancial disclosure and the cost of equity capital: The initiation of corporate social responsibility reporting. The Accounting Review, 86(1), 59-100.

Dimson, E., Karakas, O., \& Li, X. (2015). Active ownership. The Review of Financial Studies, 28(12), 3225-3268.

Eurosif. (2013). Shareholder stewardship: European ESG engagement practices 2013. https://www.eurosif.org/wp-content/uploads/2014/ 06/eurosif-report-shareholder-stewardship.pdf

Eurosif. (2018). European SRI Study 2018. http://www.eurosif.org/ wp-content/uploads/2018/11/European-SRI-2018-Study.pdf

Fiaschi, D., Giuliani, E., Nieri, F., \& Salvati, N. (2020). How bad is your company? Measuring corporate wrongdoing beyond the magic of ESG metrics. Business Horizons, 63(3), 287-299.

Grewal, J., Serafeim, G., \& Yoon, A. (2016). Shareholder activism on sustainability issues. Harvard Business School Working Paper, No. 17-003. Harvard University, Cambridge, MA. 
Guenster, N., Bauer, R., Derwall, J., \& Koedijk, K. (2011). The economic value of corporate eco-efficiency. European Financial Management, 17(4), 679-704.

Hoepner, A., Oikonomou, I., Sautner, Z., Starks, L. T., \& Zhou, X. Y. (2018). ESG shareholder engagement and downside risk. AFA 2018 paper, European Corporate Governance Institute, Finance Working Paper No. 671/2020. https://ssrn.com/abstract=2874252

Islam, M., \& Deegan, C. (2010). Media pressures and corporate disclosure of social responsibility performance information: A study of two global clothing and sports retail companies. Accounting and Business Research, 40(2), 131-148.

Kruger, P. (2015). Corporate goodness and shareholder wealth. Journal of Financial Economics, 115, 304-329.

Logsdon, J., \& Buren, H. (2009). Beyond the proxy vote: Dialogues between shareholder activists and corporations. Journal of Business Ethics, 87(1), 353-365.

Patten, D. (2002). Media exposure, public policy pressure, and environmental disclosure: An examination of TRI data availability. Accounting Forum, 26(2), 152-171.

Poulsen, T., Strand, T., \& Thomsen, S. (2010). Voting power and shareholder activism: A study of Swedish shareholder meetings. Corporate Governance: An International Review, 18(4), 329-343.

PRI. (2018). Principles for responsible investment reporting framework. Main Definitions 2018. https://www.unpri.org/Uploads/x/ 1/q/maindefinitionstoprireportingframework_971173.pdf

Rehbein, K., Logsdon, J., \& Van Buren, H. (2013). Corporate responses to shareholder activists: Considering the dialogue alternative. Journal of Business Ethics, 112, 137-154.

Reid, E., \& Toffel, M. (2009). Responding to public and private politics: Corporate disclosure of climate change strategies. Strategic Management Journal, 30, 1157-1178.

Sharfman, M., \& Fernando, C. (2008). Environmental risk management and the cost of capital. Strategic Management Journal, 29, $569-592$.
Shipman, J., Swanquist, Q., \& Whited, R. (2017). Propensity score matching in accounting research. The Accounting Review, 92(1), 213-244.

Smith, M. P. (1996). Shareholder activism by institutional investors: Evidence from CalPERS. Journal of Finance, 51(1), 227-252.

Solomon, J., \& Darby, L. (2005). Is private social, ethical and environmental disclosure mythicizing or demythologizing reality? Accounting Forum, 29, 27-47.

Solomon, J., \& Solomon, A. (2006). Private social, ethical and environmental disclosure. Accounting, Auditing and Accountability Journal, 19(4), 564-591.

Solomon, J., Solomon, A., Joseph, N., \& Norton, S. (2011). Private climate change reporting: An emerging discourse of risk and opportunity? Accounting, Auditing and Accountability Journal, 24(8), 1119-1148.

Solomon, J., Solomon, A., Joseph, N., \& Norton, S. (2013). Impression management, myth creation and fabrication in private social and environmental reporting: Insights from Erving Goffman. Accounting, Organizations and Society, 38, 195-213.

Thomsen, S., \& Conyon, M. (2012). Corporate governance: Mechanisms and systems. London: McGraw-Hill Higher Education.

Vasi, I., \& King, B. (2012). Social movement, risk perceptions, and economic outcomes: The effect of primary and secondary stakeholder activism on firms' perceived environmental risk and financial performance. American Sociological Association, 77(4), 573-596.

Publisher's Note Springer Nature remains neutral with regard to jurisdictional claims in published maps and institutional affiliations. 